\title{
Antioxidative properties of chloroplast concentrates obtained by various methods from lucerne juice
}

\author{
B. Baraniak and M. Karaś \\ Department of Biochemistry and Food Chemistry, Lublin Agricultural University \\ Akademicka 15, 20-934 Lublin, Poland
}

(Reccived 1 April 1999; accepted 8 May 2000)

\section{ABSTRACT}

The antioxidative properties and chlorophyll contents of protein concentrates obtained by various methods from lucerne were compared. Chloroplast concentrates of lucerne juice (var. Kleszczewska) were precipitated by centrifugation $(12000 \mathrm{~g})$, heating $\left(55^{\circ} \mathrm{C}\right)$, or with flocculants (Magnafloc LT-26 and Superfloc A-115). The highest antioxidative activity was obtained in the concentrate precipitated by Superfloc A-115 after $24 \mathrm{~h}$ incubation with linoleic acid. The highest chlorophyll amount was extracted from the concentrate precipitated by centrifugation; the lowest, from the preparation coagulated with Superfloc A-115.

KEY WORDS: leaf protein concentrate, antioxidative activity, chlorophyll

\section{INTRODUCTION}

Production of protein concentrates from green parts of plants was developed to obtain an additional source of protein for animal and human nutrition. Due to the high costs and small yield of the cytoplasmic fraction, such preparations are not produced on an industrial scale. In many countries (USA, France, Hungary, Australia), however, chloroplast concentrates are produced for animal feed supplementation. Their high production costs are justified by their high specific physiological activity. Studies conducted in Japan and Australia (Ostrowski-Meissner, 1993) proved the hypocholesterolemic activity of the commercial preparation, Quintessence ${ }^{\text {siv }}$, obtained by a thermal method from lucerne juice. Administration of concentrates in chicken diets lowered plasma cholesterol levels by $27.5 \%$ and 
triacyloglycerols by $34.3 \%$. Ostrowski-Meissner (1993) proposed a new name, PLEX (pigmented leaf extracts), for the traditional leaf protein concentrate LPC. The name is to underscore the physiological meaning of the compounds co-precipitated with proteins, especially natural plant pigments. Those compounds have the ability to neutralize free radicals and are therefore of great importance in the prevention and treatment of many diseases. In addition to the type of raw material, the method used to concentrate the coagulation is very important in determining the content of particular components in protein preparations (Hernández et al., 1988; Correa et al., 1989; Baraniak, 1992; Ohshima et al., 1996). In the present paper, the influence of the juice protein coagulation method on the antioxidative properties of preparations was studied.

\section{MATERIAL AND METHODS}

The material used was fresh lucerne (var. Kleszczewska) harvested in the pre-flowering phase. The green forage had previously been crushed in a screw press. The juice was extracted by pressing the green fodder in an expeller and fibrous material remaining in the juice was filtered off through a $0.15 \mathrm{~mm}=100$ mesh sieve.

Chloroplast particles in the juice were precipitated by the following methods:

- centrifugation $(12000 \mathrm{~g})$

- heat treatment $\left(55^{\circ} \mathrm{C}\right)$

- flocculation of alkalized juice $(\mathrm{pH}=7.5)$

- Magnafloc LT-26

- Superfloc A-115

Precipitated chloroplasts were washed twice with distilled water, dried at $50^{\circ} \mathrm{C}$, and as chloroplast concentrates stored at a temperature of $2-8^{\circ} \mathrm{C}$.

Proteins of chloroplast concentrates were fractionated into those:

- in soluble in phosphate buffer $\mathrm{pH} 7.0(-\mathrm{ml} / \mathrm{-g})$ by shaking $(2 \times 2 \mathrm{~h})$

- in soluble in $0.1 \mathrm{M} \mathrm{NaOH}(-\mathrm{ml} / \mathrm{g})$ by shaking $(2 \times 1 \mathrm{~h})$

Potential antioxidative substances in chloroplast concentrates, and in fractions of concentrates were extracted by an acetone water solution $(4: 1 \mathrm{v} / \mathrm{v})$ were studied. The procedure was the following : $30 \mathrm{ml}$ extraction solution was added to $0.4 \mathrm{~g}$ samples that were next shaken for $1 \mathrm{~h}$ and centrifuged for $10 \mathrm{~min}(12000 \mathrm{~g})$; the supernatant was collected and the sediment was again extracted. The process was carried out three times; the combined supernatants (extracts) were adjusted to a final volume of $100 \mathrm{ml}$.

Antioxidative activity as the ability to form conjugated diene compounds during oxidation was determined spectrophotometrically at $234 \mathrm{~nm}$ according to the method of Lingnert et al. (1979). The standard linoleic acid emulsion was pre- 
pared by mixing $2 \mathrm{ml} 10 \mathrm{mM}$ linoleic acid (Sigma) with Tween $20(2 \mathrm{ml})$ and dissolved in phosphate buffer ( $\mathrm{pH} 7.5$ ).

Test samples $(0.1 \mathrm{ml}$ of extract) were added to $0.2 \mathrm{ml}$ linoleic acid emulsion and test tubes were incubated in darkness at $37^{\circ} \mathrm{C}$ for 12,24 or $36 \mathrm{~h}$. Parallel controls in which extracts were replaced by $80 \%$ aqueous acetone were run. After cach time period, the reaction mixture was mixed with $2 \mathrm{ml}$ of methanol and $6 \mathrm{ml}$ $60 \%$ aqueous methanol and absorption at $234 \mathrm{~nm}$ was measured.

The antioxidative activity (AOA) was cxpressed as the following:

where:

$$
\mathrm{AOA}=\left[\Delta \mathrm{A}_{234(\mathrm{c})}-\Delta \mathrm{A}_{234}\right] / \Delta \mathrm{A}_{234(\mathrm{c})}
$$

$\Delta \mathrm{A}_{234}$ - increase in absorption during incubation of the cxperimental sample

$\Delta \mathrm{A}_{234(\mathrm{c})}$ - increase in absorption of the control

The chlorophyll content in the obtained acetone extracts was also measured spectrophotometrically (Arnon, 1949; Holden, 1965).

\section{RESULTS AND DISCUSSION}

The importance of compounds possessing antioxidative properties in the struggle against cancer is based on prevention of premutagenic DNA changes (Lachance, 1994). Hence, for several years scientists have been focusing on the antioxidative potential of foodstuffs of plant origin. Such properties are possessed by compounds present in seeds (Mehta et al., 1994; Tian and White, 1994; Tsuda et al., 1994), vegetables (Tsushida et al., 1994; Łatosz et al., 1997), and other plant parts (Larson, 1988).

Their biological effectiveness depends on: the type and quality of the raw material and the technical conditions of processing. The correlation between biological activity and its analytical measurements depends on the method appliedmainly on the solvent system used in the extraction (Mehta et al., 1994).

Carotenoids and polyphenols are commonly believed to be the main constituents responsible for antioxidative properties. Comparisons of the concentrations of these compounds in concentrates with values of antioxidative potential do not prove a clear relation, but in some cases a good correlation was obtained (Baraniak, 1997). Concentrates precipitated with Magnafloc LT-26 contained low levels of antioxidants, and in $24 \mathrm{~h}$ incubation, which is optimal for this method (Lingnert, 1979), also showed low antioxidative activity (Figures 1 and 2).

Lower values of antioxidative activity were obtained for preparations in which some constituents were washed out by fractionation of concentrates with phosphate buffer or sodium hydroxide and these activities were less dependent on incubation time (Table 1). 
Antioxidative activity (AOA)

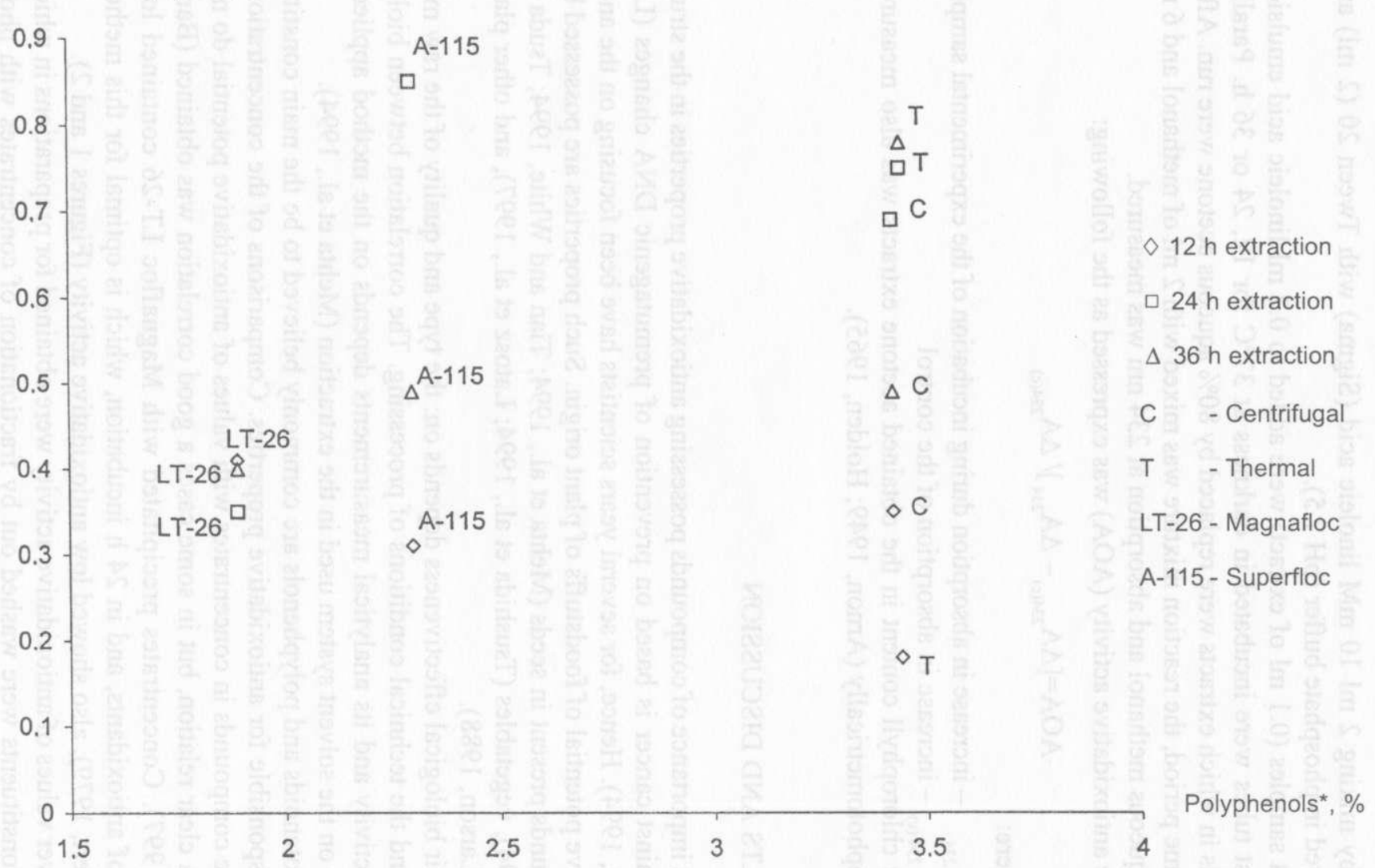

Figure 1. The relationship between antioxidantive activity and polyphenols content in proteins concentrates obtained by varius methods

* Data from Baraniak (1997) 
Antioxidative activity

(AOA)

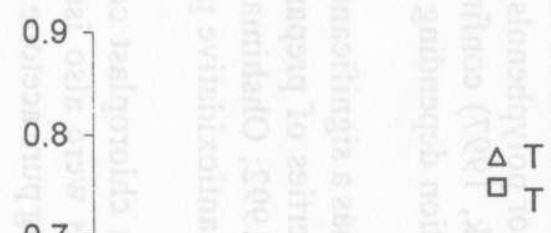

口 C

$\diamond 12 \mathrm{~h}$ extraction

$24 \mathrm{~h}$ extraction

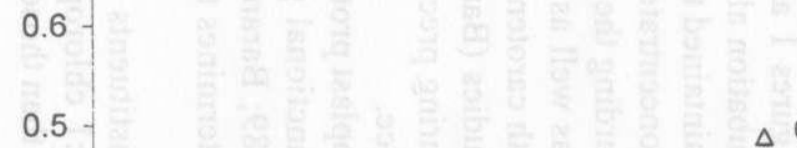

$\triangle C$

$\Delta 36 \mathrm{~h}$ extraction

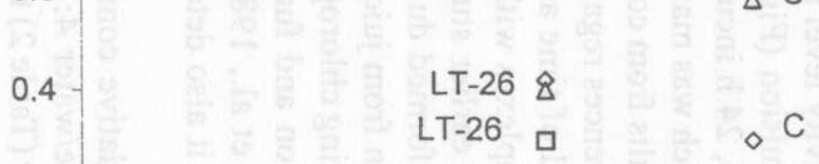

$\triangle \mathrm{A}-115$

C - Centrifugal

T - Thermal

LT-26

c

LT-26 - Magnafloc

$\diamond \mathrm{A}-115$

$\diamond \mathrm{T}$

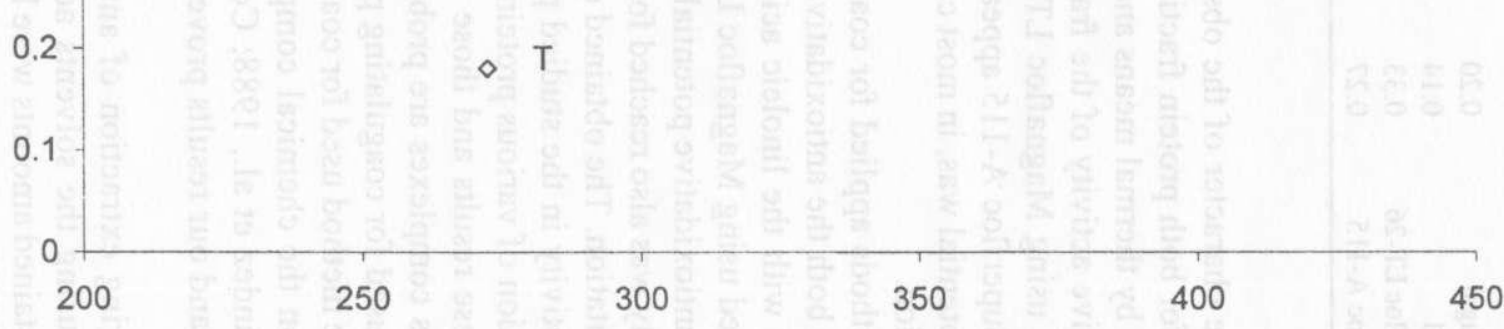

\section{Carotenes*} $\mathrm{mg} / \mathrm{kg}$

Figure 2. The relationship between antioxidantive activity and carotens content in proteins concentrates obtained by varius methods

* Level of carotens was published earlier (Baraniak, 1997) 
TABLE 1

The effect of incubation time with linoleic acid on antioxidative activity (AOA) of fraction of chloroplastic concentrates (concentration $0.1 \mathrm{mg} / \mathrm{ml}$ linoleic acid)

\begin{tabular}{lcccrrr}
\hline $\begin{array}{l}\text { Methods of } \\
\text { precipitation }\end{array}$ & \multicolumn{2}{c}{$\begin{array}{c}\text { Fraction insoluble in phosphate } \\
\text { buffer }(\mathrm{pH}=7.0)\end{array}$} & \multicolumn{3}{c}{$\begin{array}{c}\text { Fraction insoluble } \\
\text { in } 0.1 \mathrm{M} \mathrm{NaOH}\end{array}$} \\
\hline Time & $12 \mathrm{~h}$ & $24 \mathrm{~h}$ & $36 \mathrm{~h}$ & $12 \mathrm{~h}$ & $24 \mathrm{~h}$ & $36 \mathrm{~h}$ \\
Centrifugal & 0.20 & 0.30 & 0.10 & 0.30 & 0.30 & 0.13 \\
Thermal & 0.14 & 0.28 & 0.26 & 0.34 & 0.40 & 0.19 \\
Magnafloc LT-26 & 0.33 & 0.34 & 0.29 & 0.34 & 0.29 & 0.15 \\
Super1loc A-115 & 0.27 & 0.24 & 0.34 & 0.21 & 0.25 & 0.41 \\
\hline
\end{tabular}

The character of the observed changes was similar in most of the preparations for both protein fractions. The fraction insoluble in phosphate buffer obtained by thermal means and with Superfloc A-115 was an exception. The antioxidative activity of the fraction isolated with buffer from the preparation obtained using Magnafloc LT-26, and both fractions of concentrate precipitated with Superfloc A-115 appeared to be the most stable over time. The antioxidative potential was, in most cases, highest after 24 -h incubation with linoleic acid emulsion.

Methods applied for coagulation of chloroplast proteins significantly determined both the antioxidative activity level and its changes in time during incubation with the linoleic acid emulsion (Figures 1 and 2). For the concentrate obtained using Magnafloc LT-26, $24 \mathrm{~h}$ incubation allowed achieving the maximum antioxidative potential, which was maintained through the next $12 \mathrm{~h}$. High stability was also reached for results from concentrates obtained by high thermal precipitation. The obtained differences regarding the character of the antioxidative activity in the studied period of time as well as its level resulted from the formation of various protein complexes with carotenoids or polyphenols.

These results and those from earlier studies (Baraniak, 1997) confirm that various complexes are probably formed during precipitation depending on the agent used for coagulating protein from juice.

The method used for coagulating chloroplast protein has a significant influence on the chemical composition and functional properties of preparations (Hernández et al., 1988; Correa et al., 1989; Baraniak 1992; Ohshima et al., 1996) and our results prove that it also determines their antioxidative propertics.

During extraction of antioxidative constituents from chloroplast concentrates using the solvents acetone/water $4: 1$ chlorophylls were also isolated. The obtained amounts were lower (Table 2) than those using pure acetonc (Baraniak, 1997). 
The chlorophyll content was significantly different among the preparations under study. Their highest amount was extracted from concentrates obtained by centrifuging (Table 2), the lowest from preparations flocculated with Superfloc A-115. The percentage of chlorophyll ,a" in total chloroplast chlorophyll concentrate was the highest in the thermally precipitated preparation, the lowest, in the centrifuged one (Table 2).

Chlorophylls are stable only in the natural form in which they occur in chloroplasts: bound to proteins, phospholipids or other constituents. Disturbing the native structures during technological processes (heating, grinding, dissolving) causes colour changes due to chlorophyll transformations (Wilska-Jeszka, 1994). The chlorophyll content in protein concentrates can be modified by introducing chosen chemicals into ground raw material (Baraniak et al., 1990) or extracted juice (Baraniak, 1996). Our results confirm earlier observations of Baraniak (1997) that the concentrate coagulation method determines the chlorophyll content as well. In the present paper, no correlation was found between the chlorophyll level in extracts and their antioxidative potential. Our results indicate that the ratio of both chlorophyll forms rather than their content in extracts affects antioxidative activity.

TABLE 2

The chlorophyll content of chloroplastic concentrates dry matter $(\mathrm{mg} / \mathrm{kg})$ obtained from lucerne juice by various methods

\begin{tabular}{|c|c|c|c|c|c|c|c|c|c|}
\hline \multirow{4}{*}{$\begin{array}{l}\text { Methods of } \\
\text { precipitation }\end{array}$} & \multicolumn{9}{|c|}{ Fraction of chloroplastic concentrate } \\
\hline & \multicolumn{3}{|c|}{ chloroplastic } & \multicolumn{3}{|c|}{$\begin{array}{l}\text { insoluble in phosphate } \\
\text { buffer }(\mathrm{pH}=7.0)\end{array}$} & \multicolumn{3}{|c|}{$\begin{array}{c}\text { insoluble in } 0.1 \mathrm{M} \\
\mathrm{NaOH}\end{array}$} \\
\hline & \multicolumn{3}{|c|}{ chlorophyll } & \multicolumn{3}{|c|}{ chlorophyll } & \multicolumn{3}{|c|}{ chlorophyl] } \\
\hline &,$a "$ & .b" & $\begin{array}{l}. a " \% \\
\text { of total }\end{array}$ &,$a "$ & ,b” & $\begin{array}{l}\text { „a" \% } \\
\text { of total }\end{array}$ &,$a "$ & ..b" & $\begin{array}{l}\text {,a"\% } \\
\text { of total }\end{array}$ \\
\hline Centrifugal & 1.09 & 0.98 & 53 & 3.35 & 1.89 & 64 & 0.77 & 0.22 & 78 \\
\hline Thermal & 1.46 & 0.53 & 73 & 3.19 & 2.76 & 54 & 0.76 & 0.63 & 55 \\
\hline Magnafloc LT-26 & 0.90 & 0.43 & 68 & 2.94 & 1.03 & 74 & 0.76 & 0.15 & 84 \\
\hline Superfloc A-115 & 0.48 & 0.26 & 65 & 2.52 & 1.39 & 65 & 0.74 & 0.60 & 55 \\
\hline
\end{tabular}

\section{CONCLUSIONS}

The concentration of carotenoids and polyphenols affects the level of antioxidative activity, but there is no linear relation when it is measured by oxidation of linoleic acid emulsion. The antioxidative potential of chloroplast concentrates depends on the method applied to obtain them and is more dependent on the ratio of ,a" and „, 


\section{REFERENCES}

Arnon D.J.. 1949. Copper enzymes in isolated chloroplasts polyphenoloxidase in Beta vulgaris. Plant Physiol. 24, 1-15

Baraniak B., 1992. Chemical composition and functional properties of protein concentrates obtained from juice of the sunflower leaves (in Polish) Rocz. Nauk rol. B-108 (1/2), 103-112

Baraniak B., 1996. Chlorophyll content in protein concentrates flocculated from alfalfa juice with chosen substances as protease inhibitors. Proceedings of the 5-th International Congress on Leaf Protein Research „LEAFPRO-96”, Vol. 2 „Green vegetation fractionation for food purposes". Rostov-on-Don (Russia), pp. 148-152

Baraniak B., 1997. Chemical composition and protein digestibility of chloroplastic concentrates from lucerne juice coagulated using various methods. J. Anim. Feed Sci. 6, 137-144

Baraniak B., Bubicz M., Niezabitowska M., 1990. Influence of preserving preparations on chlorophyll in juices from green parts of plants (in Polish) Rocz. Nauk rol. B-106 (3/4), 31-37

Correa A.D. Espindola F.S., Tanaka T.N., Piau R. Jr., 1989. Comparative study of various methods of leaf protein extraction and precipitation. Proceedings of the $3 \mathrm{rd}$ International Conference on Leaf Protein Research „LEAFPRO-89”. Pisa, Perugia, Viterbo (Italy), pp. 447-449

Hernández A., Martinez. C., Gonzálcz G., 1988. Effects of freezing and $\mathrm{pH}$ of alfalfa leaf juice upon the recovery of chloroplastic protein concentrates. J. Agr. Food Chem. 36, 139-143

Holden M., 1965. Chlorophylls. In: T.W. Goodwin (Editor). Chemistry and Biochemistry of Plant Pigments. London, Academic Press, pp. 461-488

Lachance P.A., 1994. Micronutrients in cancer prevention. In: Mou-Tuan Huang. Toshihiko Osawa, Chi-Tang Ho, R.T. Rosen (Editors). Food Phytochemicals for Cancer Prevention. American Chemical Soc., Washington, DC, pp. 49-64

Larson R.A., 1988. The antioxidants of higher plants. Phytochemistry 27, 969-978

Lingnert H., Vallentin K.V., Eriksson C.E., 1979. Measurement of antioxidative effect in model system. J. Food Process Preserv. 3, 87-103

Latosz A., Piskuła M., Kozłowska H., 1997. The liposome method of determination the antioxidative properties of Cruciferae vegetables (in Polish). Proceedings of 2 nd Sesion of Food Analysis. Warszawa (Poland), p. 21

Mehta R.L., Zayas J.F., Yang S.S., 1994. Ajowan as a source of natural lipid antioxidant. J. Agr. Food Chem. 42, 1420-1422

Ohshima M.. Proydak N., Nishino N., 1996. Rełationships among coagulation methods, yield and nutritive values of LPC. Proceedings of the 5-th International Conference on Leaf Protein Research „LEAFPRO-96“. Vol.1 .,Green vegetation fractionation for fodder purposes”. Rostovon-Don (Russia), pp. 61-68

Ostrowski-Meissner H.T., 1993. Pure pigmented leaf extract Quintessence as a natural egg yolk pigmentor with cholesterol reducing potency. Proceedings of VII World Conference on Animal Production. Canada, pp. 394-395

Tian L.L., White P.J., 1994. Antioxidant activity of oat extract in soybean and cottonseed oils. J. Amer. Oil Chem. Soc. 71, 1079-1086

Tsuda T., Watanabe M.. Ohshima K., Yamamoto A., Kawakishi S., Osawa T., 1994. Antioxidative components isolated from the seed of tamarind (Tamarindus indica L.). J. Agr. Food Chem. 42. $2671-2674$

Tsushida T., Suzuki M., Kurogi M., 1994. Evaluation of antioxidant activity of vegetable extracts and determination of some activites compounds. Nippon Shokuhin Kogyo Gakkaishi 41, 611-618

Wilska-Jeszka J., 1994. The pigments. In: E. Sikorski (Editor). Chemical and Functional Properties of Food Components (in Polish). WNT, Warszawa (Poland), pp. 407-412 


\section{STRESZCZENIE}

Właściwości antyutleniajace koncentratów chloroplastycznych otrzymanych z soku lucerny różnymi metodami

Porównano właściwości antyutleniające koncentratów chloroplastycznych z lucerny otrzymanych różnymi metodami. Koncentraty chloroplastyczne z soku lucerny (odm. Kleszczewska) otrzymywano poprzez wirowanie $(12000 \mathrm{~g})$, termicznie $\left(55^{\circ} \mathrm{C}\right)$ lub wytrącanie flokulantami Magnafloc LT-26 i Superfloc A-115. Największy efekt antyutleniajacy stwierdzono w koncentracie wytrąconym flokulantem Superfloc A-115 po 24-godzinnej inkubacji z kwasem linolowym. Najwiekszą ilość chlorofili wyekstrahowano natomiast z koncentratu otrzymanego poprzez wirowanie, najniższą zaś z preparatu koagulowanego flokulantem Superfloc A-115. 